\title{
The health effects of radon and uranium on the population of Kazakhstan
}

\author{
Rakmetkazhy I. Bersimbaev* and Olga Bulgakova
}

\begin{abstract}
The radioactive contamination is a significant factor affecting the environment and human health. Radon and its decay products are the major contributors to human exposure from natural radiation sources. World Health Organization has identified the chronic residential exposure to radon and its decay products as the second cause of lung cancer after tobacco consumption and also as the main risk-factor in never smokers. The high levels of radon are observed in the North and East areas of Kazakhstan because of the natural radiation sources and the long-term and large-scale mining of uranium. The genotoxic effects of radon on population of Kazakhstan are poorly understood, in spite of the fact that many regions of the country contain the high levels of radon. Studies elucidating potential health risk among population exposed to radon and genotoxic effect of radon in Kazakhstan are very limited or they have never been addressed in some areas. In this review, we are presenting available data on the residential radon exposure of humans in uranium mining and milling areas in the North and East areas of Kazakhstan.
\end{abstract}

Keywords: Lung cancer, Cancer risk, Radon, Uranium, Radioactivity screening

\section{Introduction}

Kazakhstan is the second largest republic by the territory among the former New Independent State countries. It has rich natural resources such as minerals, metal ores, natural gas and oil reserves. Such vast resources have stimulated the former Soviet Union to develop specific and intensive industries in the territory. Now it is wellknown that the Semipalatinsk region in the north-eastern Kazakhstan was used for testing nuclear weapons for the Soviet army during the period 1949-1989 [1-3]. During the testing period, several hundred thousand people in Semipalatinsk, the Eastern Kazakhstan, Pavlodar regions of Kazakhstan and Altay region of Russian Federation were repeatedly exposed to radioactive fallout [4]. Radionuclides emanating from these tests resulted in atmospheric and environmental contaminations leading to various levels of acute and chronic radiation exposures. Long-lived radionuclides such as strontium and plutonium are present in these areas. Health effects of radiation released as a result of the tests remain as a serious concern $[4,5]$.

\footnotetext{
* Correspondence: ribers@mail.ru

Institute of Cell Biology and Biotechnology, Department of General Biology and Genomics, L.N.Gumilyov Eurasian National University, Munaitpassov str.5, 010008 Astana, Kazakhstan
}

Uranium also has been actively mined and milled in the Republic of Kazakhstan [6]. Uranium ore mining and processing were initiated in Kazakhstan shortly after Second World War, and lasted for almost half a century. It has been estimated that during the Soviet period about $30-40 \%$ of the uranium was extracted from the Asian region $[7,8]$.

Kazakhstan has $12 \%$ of the world's uranium resources and an expanding mining sector, producing about 22,830 tonnes in 2014, and planning for further increase to 2018 [9]. The mining and milling of uranium ore in the North and East Kazakhstan have caused contamination of the environment through a number of activities, specifically the open pit mining process, transportation to and from milling sites, the milling and processing of ore, and open-air storage of radioactive and nonradioactive mining wastes.

Kazakhstan might be exposed to a variety of hazardous materials including radon, a radioactive gas occurring naturally as an indirect decay product of uranium. The main concern in Kazakhstan is that approximately $85 \%$ of the urban population lives in territories where environmental pollution is known to be exceeded permissible standards $[10,11]$ together with 
vastly unknown contamination problems. The role of radon and its radioactive decay products as human carcinogens has been established by the International Agency for Research on Cancer in 1988 and is supported by the experimental evidences obtained by the laboratory experiments on animals [12] and epidemiologic studies in humans [13]. In 2009, the World Health Organization identified the chronic residential exposure to radon and its decay products as the second cause of lung cancer after tobacco consumption and as the main risk-factor in never smokers [14]. The problem of the health-risk exposed to radon is not sufficiently studied on the populations of Kazakhstan, although the country has the regions containing the high levels of radon [15]. From this short information, it can be concluded that one of the priorities of biomedical sciences of Kazakhstan is the investigation of environmental health concerns that can be caused by known and potentially unknown environmental hazardous substances. Taking into account the importance of residential radon as a risk factor for lung cancer, in this review we are presenting available data on radon/uranium exposure of human in uranium mining and milling areas in North and East of Kazakhstan.

\section{Uranium sources in Kazakhstan}

As noted before the Republic of Kazakhstan is a leader in the world reserves of uranium ores. Kazakhstan has $12 \%$ of the world's uranium resources and an expanding mining sector, producing about 22,830 tons in 2014 [9]. In 2009 it became the world's leading uranium producer, with almost $28 \%$ of world production, then $38 \%$ in 2013 [9]. The largest regions enriched with the uranium deposits are located within the North Kazakhstan containing approximately $16.4 \%$ of the uranium resources of Republic [16]. Besides, there are also large storage facilities for the radioactive waste in the North and West Kazakhstan. The total area exposed to radioactive waste from the uranium industry enterprises is estimated to approximately 100,000 hectares with a total activity of 250,000 Curie. In mining, the uranium and its decay products buried deep in the earth are brought to the surface, and the rock containing them is crushed into fine sand. After the uranium is chemically removed, the sand is stored in huge reservoirs [17]. Conservation and liquidation of uranium deposits in northern Kazakhstan was completed in 2008 in accordance with the State program "Preservation of non-uranium mining enterprises and liquidation of the consequences of uranium deposits for 2001-2010" [18].

Natural background radiation in regions of Kazakhstan is highly diverse and on average it is $3.1 \mathrm{mSv} /$ year [19]. The population additionally receives about $1.1 \mathrm{mSv} /$ year during the medical procedures. Thus, the total dose of artificial and natural radiation in the average per person in Kazakhstan is about $4 \mathrm{mSv} /$ year, which is one and a half times higher than the world's average level [20]. The annual effective dose of the population living near radioactively contaminated territories in North Kazakhstan was very high. For example, these doses were about 7.9 and $8.1 \mathrm{mSv} /$ year in two settlements "Aksu" and "Saumakol", respectively [10].

Uranium (U) is a radioactive chemical element of group III of the periodic system with atomic number 92 that belongs to the family of actinides. Uranium is readily soluble in water, easily reacts with the basic elements of organic compounds. In nature, uranium is found as uranium-238, uranium-235, and a very small amount of uranium-234. Uranium is not considered carcinogenic in humans, and direct evidence on the carcinogenicity in humans from different types of uranium, compounds and isotopes is limited [21]. However, depleted uranium has a chemical toxicity that is independent of its radioactivity [22]. The uranium affects all organs and tissues, as a cell poison. Large doses of uranium cause damage to the kidneys [23]. Uranium may also be associated with genotoxicity effects. At a molecular level, uranium and other metals may also induce genomic instability by affecting pathways like DNA repair, regulation of nuclear transcription factors, gene expression regulation, apoptosis, cell growth, reactive oxygen species (ROS) generation by replacing essential metals in their metabolic pathways [24]. All these effects may lead to the development of serious diseases such as cancer. Epidemiological studies of uranium miners showed a strong association of radon exposure and lung cancer risk [25].

\section{Health risks of radon}

Radon is a chemically inert radioactive gas, occurring naturally as an indirect decay product of uranium. The most stable isotope is ${ }^{222} \mathrm{Rn}$, which is a decay product of ${ }^{238} \mathrm{U}$ and ${ }^{220} \mathrm{Rn}$ occurs in the decay chain for ${ }^{232} \mathrm{Th}$. Contribution to the total radiation dose from ${ }^{222} \mathrm{Rn}$ is approximately 20 times greater than those of ${ }^{220} \mathrm{Rn}$, but for convenience and on the advice of United Nations Scientific Committee on the Effects of Atomic Radiation (UNSCEAR) isotopes are not differentiated and are considered together. This implies that most of the radiation is not so much from the radon as from its decay daughter products [26]. It was established that alphaparticle emissions from inhaled radon progeny cause lung cancer [27]. According to World Health Organization [14] epidemiological studies have provided convincing evidence of an association between indoor radon exposure and lung cancer, even at the relatively low radon levels commonly found in residential buildings. Radiation dose due to radon and progeny depends on concentration, 
particle size distribution, respiratory deposition, and lung clearance [25].

Radon comes into the residential rooms through the foundation or standing out from the building materials. As a result, there can be high levels of radiation in the room. Furthermore, radon enters into the house via tap water and cooking gas. The contribution of radon in the formation of an average human dose is estimated to be more than $50 \%$, so the radionuclides of radon are responsible for more than a half of the total dose of radiation, which receives an average human body from natural and man-made radionuclides environment [25].

The general effects of radon to the human body are caused by its radioactivity and it consequently carries a risk of radiation-induced cancer. In the studies of uranium miners, the workers who were exposed to the high levels of radon have shown an increased frequency of chromosomal aberrations in blood lymphocytes. Many studies have shown a correlation between the frequency of chromosomal abnormalities and a cancer risk [28-30]. Popp et al. [28] studied the chromosomal aberrations as biomarkers of genetic damage in blood lymphocytes of the former East German uranium miners who have been exposed to radon for estimation health risk for lung carcinogenesis. The authors found an increase of the frequency of chromosomal aberrations in blood lymphocytes of radon exposed population in comparison with control population. In experiments of Wolf et al. [29], it was demonstrated an increase in chromosomal aberrations in human peripheral lymphocytes after in vitro exposure to 18 cGy of radon and its progeny.

Increased risk of lung cancer in radon-exposed miners with elevated frequency of chromosomal aberrations was demonstrated by Smerhovsky et al. [30]. By using the Cox regression models, which accounted for the age at time of first cytogenetic assay, radon exposure they showed strong and statistically significant associations between cancer incidence and frequency of aberrant cells, respectively. A $1 \%$ increase in the frequency of aberrant cells was paralleled by $62 \%$ increase of cancer. A causal relationship between radon exposure and lung cancer is defined also by many other authors [31-33]. This is confirmed by numerous studies of lung cancer mortality in uranium miners groups due to radon $[34,35]$.

In the literature there are different data on the histological types of lung cancer induced by radon. Some studies have reported that radon increases the risk of small-cell lung cancer. Barros-Dios and colleagues [36] found that less frequent histologic types (including large cell carcinomas), followed by small cell lung cancer, had the highest risk associated with radon exposure. According to the study of Taeger et al. [37] a small cell lung cancer and squamous carcinoma is associated with the radon exposure, but adenocarcinoma is associated less.
Some studies have found a positive correlation between the incidence of adenocarcinoma in the group of nonsmoking women and the increasing concentration of radon in the living room [38].

Some studies have showed a statistically significant relation between cumulative radon exposure and the risk of extra pulmonary cancers [39, 40]. However, most of researchers think that the risk factor for bronchial tubes by radon inhalation is much higher than for the other organs of the human body. The main targets for the cancer induction are the segmental bronchia [41].

Radon exposure is considered the first cause of lung cancer in never smokers [42]. The aim of the study of Torres-Duran et al. [42] was to assess the effect of residential radon exposure on the risk of lung cancer in never-smokers and to ascertain if environmental tobacco smoke modifies the effect of residential radon. The authors demonstrated that individuals exposed to environmental tobacco smoke and to radon concentrations $>200$ Bq. $\mathrm{m}^{3}$ had higher lung cancer risk than those exposed to lower radon concentrations and exposed to environmental tobacco smoke. Kreuzer et al. [43] in their studies also showed that lung-cancer risk associated with radon exposure in never smokers.

Radon can enhance effects of other factors such as cigarette smoke, dust, and exhaust gases. Tobacco smoke increases the oncogenic effect of radon by 2 to 10 times and, most importantly, radon significantly reduces the latency period for lung cancer $[44,45]$. Studies conducted by the United States Environmental Protection Agency showed that radon-related lung cancer diseases among smokers are three times higher than nonsmokers of the same population [46]. As reported by Darby et al. [47] cumulative risk of lung cancer when reaching the age of 75 years is estimated to never smokers at $0.4 \%, 0.5 \%$ and $0.7 \%$ for the radon concentrations of 0,100 and $400 \mathrm{~Bq} / \mathrm{m}^{3}$, respectively. While cumulative risk of lung cancer at the age of 75 years for smokers, reaching $10 \%, 12 \%$ and $16 \%$ for radon concentrations of 0,100 and $400 \mathrm{~Bq} / \mathrm{m}^{3}$ [47].

According to the United Nations Scientific Committee on the Effects of Atomic Radiation, radon is responsible for about $20 \%$ of all lung cancer diseases in the world. Exposure to radon is the second leading risk factor, causing approximately 21,000 cases of lung cancer per year in the United States [48]. British Radiation Protection Bureau reports that in the UK 1400 people die each year from radon-induced lung cancer [49]. Case-control study carried out in Spain showed that the risk of lung cancer with radon exposed to $147 \mathrm{~Bq} / \mathrm{m}^{3}$ increase in two times [36]. According to the research of the Canadian scientists, the relative risk of lung cancer in nonsmokers living with radon exposed to $200 \mathrm{~Bq} / \mathrm{m}^{3}$ is 
doubled and compared with the control group [50]. Peterson and colleagues [51] showed that in Ontario (Canada), $13.6 \%$ of deaths from lung cancer caused by radon action. Based on the assessment the Government of Canada revised the guideline for the exposure to radon in indoor air from $800 \mathrm{~Bq} / \mathrm{m}^{3}$ to $200 \mathrm{~Bq} / \mathrm{m}^{3}$ in June 2007 [52]. The population study in Russia has shown that people who were exposed to radon had significantly increased risk of lung cancer [53]. Similar results were also obtained in the study of the risk of radon-induced lung cancer in Chihuahua (Mexico) [54]. In Denmark, from 1993 to 1997 the living conditions of 57.053 people studied, and analysis of the results showed a positive correlation between the incidence of lung cancer and radon indoors [55]. Thus, epidemiological studies conducted in different countries, indicate the existence of an association between a high content of radon and the risk of lung cancer.

However, the problem of the health effect of radon on the Kazakhstan population is poorly understood. Studies elucidating potential health risk among population exposed to radon and genotoxic effect of radon in Kazakhstan are limited or absent in some areas.

\section{Indoor radon data in the East and North Kazakhstan}

The rocks with high radioactivity and tectonic faults with the high emanation can lead to a significant increase of radon concentration indoor and its contribution becomes dominant in the collective dose of the population. According to the experts the contribution of natural sources in the average annual radiation dose of the Kazakhstan population currently stands at $80 \%$, including $50 \%$ from radon. In some settlements in $70 \%$ of the buildings radon concentration exceeds the maximum permissible concentration $\left(200 \mathrm{~Bq} / \mathrm{m}^{3}\right)$. There are official data showing that the concentration of radon in the soil in some areas of Kazakhstan reaches 300 $000 \mathrm{~Bq} / \mathrm{m}^{3}$, and the concentration of indoor reaches $6000-12,000 \mathrm{~Bq} / \mathrm{m}^{3}$, which exceeds the maximum permissible concentration in 60 times [56].

In 2005-2007, a three-year project "The study of the negative impact of natural radioactivity (radon) on public health." was carried out in Kazakhstan by the Ministry of Environment Protection. This study identified the radon areas in the North, East and in the central part of the country. A high level of radon in water sources and in indoor air was detected in these areas. A high value of equivalent equilibrium volume activity of radon (EEVA) was revealed in East Kazakhstan. Instantaneous value of radon EEVA surveyed localities reaches 8000$9000 \mathrm{~Bq} / \mathrm{m}^{3}$. Among 222 surveyed facilities (schools, hospitals, houses), the exceeding standards of radon were observed in 71 cases (35\%) [57].
As reported on the official website of the Department of Natural Resources of the East Kazakhstan for the period 1990-1992 in the city of Ust-Kamenogorsk, 137 radioactive anomalies and pollution of various origins with the radiation power in places up to $7000 \mathrm{mR} / \mathrm{h}$, at a rate of 18-20 mR / h were revealed. Measurements of instantaneous values of EEVA conducted in 2005 in the buildings of hospitals, the private homes of the city showed the presence of levels of radon EEVA in the air space in the range of 5 to $2349 \mathrm{~Bq} / \mathrm{m}^{3}$ (Fig. 1). On 22 objects instant values of equivalent equilibrium volume activity of radon over $200 \mathrm{~Bq} / \mathrm{m}^{3}$ were recorded in residential and public buildings and on 8 objects EEVA level was more than $340 \mathrm{~Bq} / \mathrm{m}^{3}$. It is believed that the level of effective dose of the East Kazakhstan population due to radon is 1.5 times more than the average in the world [58].

In accordance with the average value of radon EEVA obtained in 2004-2005, the expected annual individual effective dose of internal exposure of Ust-Kamenogorsk population will be more than $5 \mathrm{mSv} /$ year. According to the sanitary rules and regulations in Kazakhstan, this value is characterized as a high level of public exposure from natural sources of radiation and makes it necessary to conduct some anti-radiation protective measures. During the study in the Altai (East Kazakhstan) region, 15 of the 18 settlements were identified with excess of radon concentration (from 200 to $8000 \mathrm{~Bq} / \mathrm{m}^{3}$ ) [59].

Stegnar et al. [7] measured indoor ${ }^{222} \mathrm{Rn}$ concentrations in 27 selected houses and public buildings in UstKamenogorsk city. According to their data the values of radon is ranged from 22 to $2100 \mathrm{~Bq} / \mathrm{m}^{3}$, the average concentration of radon was $230 \mathrm{~Bq} / \mathrm{m}^{3}$. The corresponding annual effective doses ranged from 0.5 to $20 \mathrm{mSv}$, the average dose being $5 \mathrm{mSv}$ per year.

The territory of North Kazakhstan is characterized by the areas with the high levels of radiation, arising both from natural radiation sources, as well as by long-term and the large-scale activities of uranium mines and uranium processing companies [60].

In Akmola province located a large region one of the world's largest North Kazakhstan uranium ore province. It contains more than 30 uranium deposits [61]. More than 50 years in North Kazakhstan being open and underground mining of uranium ore were resulted in the region where has accumulated a significant amount of radioactive waste with the high-risk as a source of radioactive contamination of the environment and harmful to human health. All these factors contribute to the formation of elevated concentrations of radon in the region. The measurement of the radon activity in indoor air was carried out in 2010 on the territory of three districts of Akmola region. As a result of this work there have been revealed 47 settlements, including the new capital of 


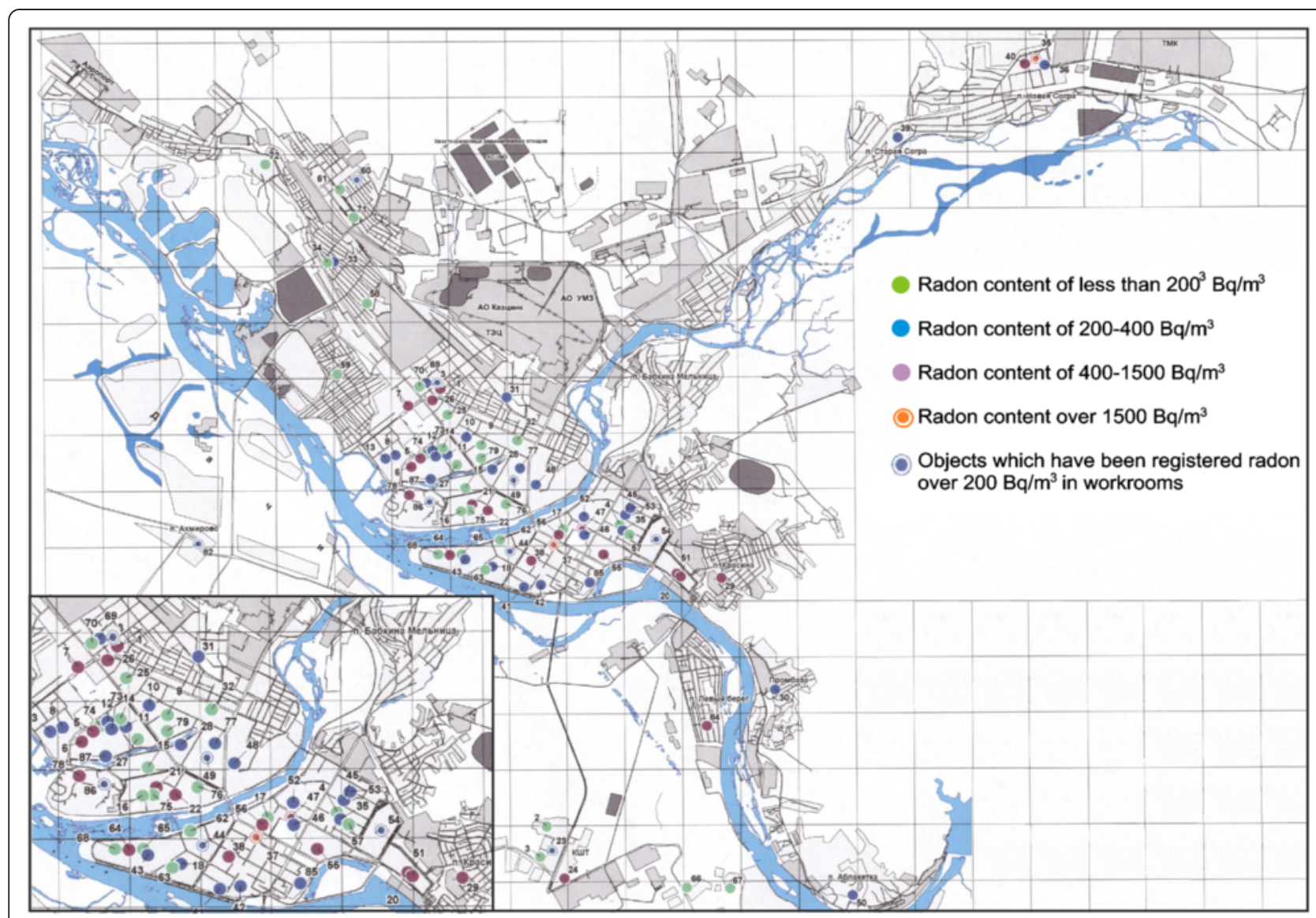

Fig. 1 The map of radon in indoor air of Ust-Kamenogorsk (East Kazakhstan) [57]. In the lower left part of the map radon contents (dots) shown in the increased scale

Kazakhstan Astana city and Kokshetau city, 35 settlements $(76.1 \%)$ which were characterized by excess of standard values $\left(200 \mathrm{~Bq} / \mathrm{m}^{3}\right)$ radon activity [56].

In 2010, 814 measurements of radon in indoor air of the residential and public buildings were carried out in Astana in order to implement the preventive health surveillance. Exceeding levels of radon has been established in eight newly built homes $\left(207-1150 \mathrm{~Bq} / \mathrm{m}^{3}\right)$. It was also revealed the excess of radon activity in the village school Balkashino $\left(1022 \mathrm{~Bq} / \mathrm{m}^{3}\right)$ and in the preschool of the village "Shantobe" $\left(789 \mathrm{~Bq} / \mathrm{m}^{3}\right)$. State Medical Academy revealed maximum values ${ }^{222} \mathrm{Rn}$ activity in the settlements: Vasilkivka - $866 \mathrm{~Bq} / \mathrm{m}^{3}$, Granite $611 \mathrm{~Bq} / \mathrm{m}^{3}$, Ondiris - $419 \mathrm{~Bq} / \mathrm{m}^{3}$. In the village of Aksu, there were 42 surveyed areas in which 22 cases were detected exceeding the permissible radon activity. Activity of radon in homes ranged from 8 to $858 \mathrm{~Bq} / \mathrm{m}^{3}$, in schools - 153-2162 Bq / m3 and in the basement - $130-5870 \mathrm{~Bq} / \mathrm{m}^{3}$. In the village Saumalkol the value of radon activity was in the range from 590 to $3977 \mathrm{~Bq} / \mathrm{m}^{3}$. In some other areas of the North Kazakhstan region (Akkol, Yenbekshilder and Sandyktau) 112 settlements were examined (Fig. 2).
More than $60 \%$ of the settlements were identified with exceeding the activity of radon in indoor air and the drinking water sources in $32 \%$ of villages. The most famous case of a high level of radon in mines and in a residential area in Kazakhstan is mine "Akchatau". It is under a comprehensive survey of radon in mines and homes, as well as the health of miners and residents. As a result, it has been found that the incidences of respiratory diseases, nervous system, cardiovascular system exceed the average for the region is 2.9 times. It is most likely indicative of radon exposure on the health of the village. It should be noted that such studies, unfortunately, are rare in Kazakhstan and in insufficient quantities [56].

\section{Radon concentrations in drinking water in the East and North Kazakhstan}

The active study of the concentrations of the natural radioactive elements in natural waters in Kazakhstan began in the late 40 's of the last century due to an increase in geological prospecting for radioactive materials. From 1960 to 1992 the entire territory of Kazakhstan was covered the hydrogeological surveys for water supply of the settlements. To carry out these activities in 


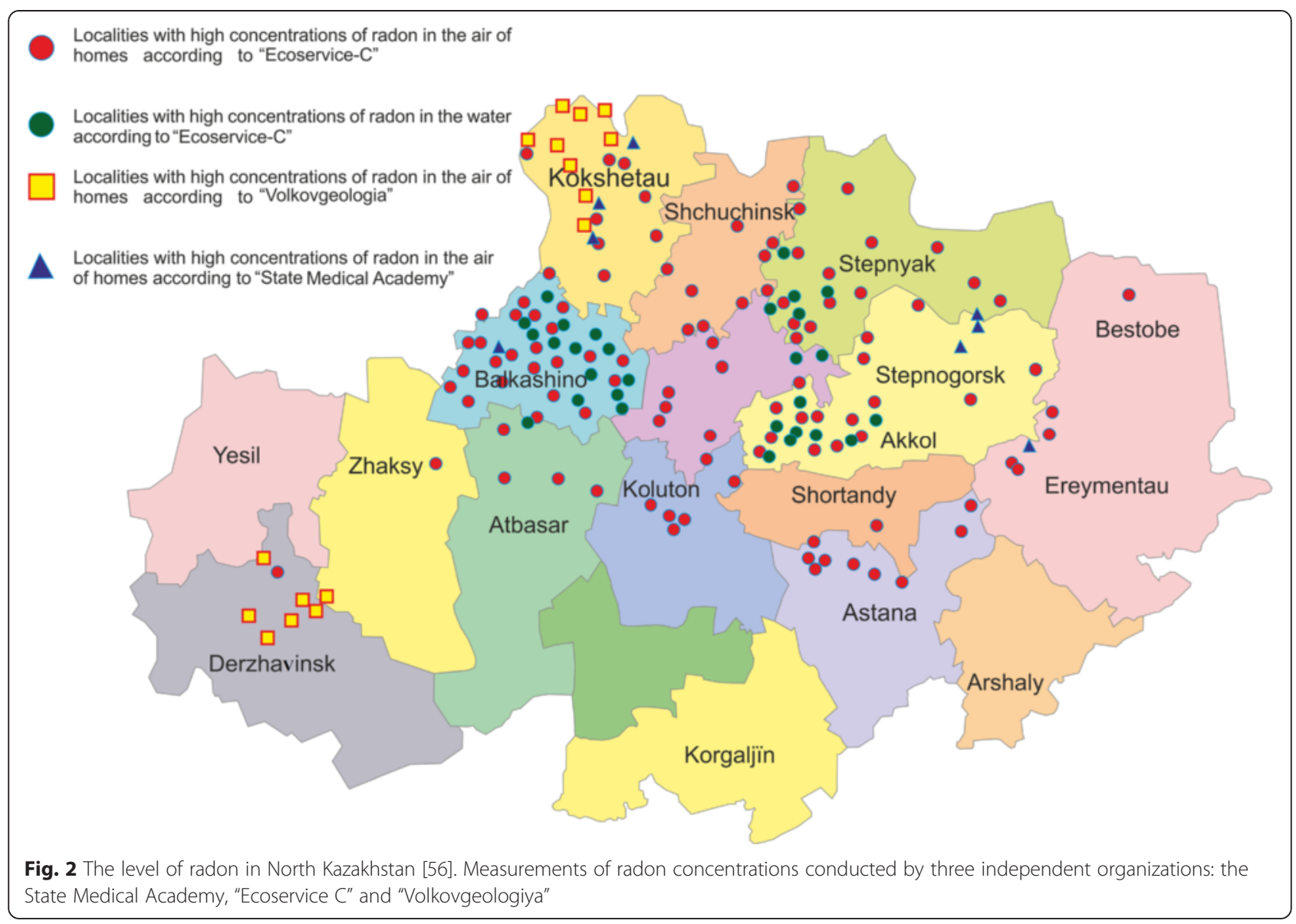

large volumes, the strictly regulated selections of water samples were conducted for determination of uranium, radium and radon. The amount of available information in the archives and reports of specialized organizations includes information on approximately 30,000 water sources [10]. It has been shown that in the drinking water of some settlements specific activity for ${ }^{238} \mathrm{U}$ reached $96 \mathrm{~Bq} / \mathrm{l}$, activity for ${ }^{226} \mathrm{Ra} 45 \mathrm{~Bq} / \mathrm{kg}$, and activity for ${ }^{222} \mathrm{Rn} 5100 \mathrm{~Bq} / \mathrm{kg}$ respectively [62].

The radiological evaluations of drinking water were carried according the norms established by "Sanitary requirements for radiation safety" representing the main technical document regulating norms of ionizing radiation in Kazakhstan. According to this document, the contents of the natural and artificial radionuclides in drinking water, creating an effective dose of less than $0.1 \mathrm{mSv} /$ year, does not require measurements to reduce the radioactivity of drinking water [63]. Over the past five years in Akmola region (North Kazakhstan) were investigated 1271 drinking water samples, from which 550 samples did not meet the standards for total alpha activity (43\%). On average, the radiation dose of the population received drinking water is $0.21 \mathrm{mSv} /$ year in the region [56].
Thus, the studies of groundwater sources in North Kazakhstan have shown the presence of radon in drinking water sources from 8 to $300 \mathrm{~Bq} / \mathrm{l}$. The 32 surveyed drinking sources in 15 cases (47\%) had the high levels of radon in drinking water [56].

The studies of groundwater in Ust-Kamenogorsk (East Kazakhstan), conducted in 2005, showed fluctuations in the level of radon $\left({ }^{222} \mathrm{Rn}\right)$ in the range of $8.0 \mathrm{~Bq} / \mathrm{l}$ to $81 \mathrm{~Bq} / \mathrm{l}$ at a rate of radon in drinking water of $60 \mathrm{~Bq} / \mathrm{l}$ [56].

The concentration of radon in drinking groundwater may be associated with the presence of water in its longlived daughter product ${ }^{210} \mathrm{~Pb}$, which is one of the most radiotoxic beta-active natural radionuclides. Apart from the natural radioactivity of soil, a main source of radon in the environment is a waste of uranium industry.

\section{Health effect of radon and uranium on the population in Kazakhstan}

The analysis of medical statistics of North Kazakhstan showed that the level of overall mortality and cancer among adults and children is one of the highest in the region [64], although it has not revealed a direct relationship between these indicators and the radiation 
factor as a result of uranium mining and processing enterprises.

The production of uranium involves a large contingent of workers whose work takes place in the specific conditions exposing to radiation and chemical factors present in the ore mined. Klodzinskiy A. and colleagues [65] have shown a deterioration of health at uranium miners in North Kazakhstan. The results of epidemiological and medical studies find out the high frequency of respiratory diseases $(61 \%)$ in the cohort of uranium miners of North Kazakhstan. The main form of pathological changes was degenerative disorders in the form of atrophic rhinopharyngitis [65].

According to Djumasheva R. and Kazymbet P. [66] the most common somatic diseases among uranium workers of Stepnogorsk city were hypertension, chronic obstructive pulmonary disease and chronic gastritis. Moreover dysfunction of all parts of the immune system was observed in the studied groups of uranium workers [67]. Comprehensive clinical assessment of health status of children and adults living near Stepnogorsk uranium processing enterprises showed a high risk of developing chronic diseases of internal organs due to long-term toxic effects of radiation. The study of reproductive health of women living in areas adjacent to the uranium mines showed a low percentage of healthy women (13\%) [68]. Among children of Stepnogorsk city the urinary tract infections and chronic bronchitis amounted to a high percentage of the total somatic pathology's number [69].

In our previous study [70, 71] uranium mine-workers in the Stepnogorsk mining-milling complex in North Kazakhstan were investigated for the expression of chromosome aberrations and for genetic factors that can modify the exposure related expression of chromosome damage. The study has demonstrated an increased frequency of chromosomal aberrations in uranium miners compared to the matched control subjects, which were not exposed to uranium compounds or to any other known chemical or physical mutagens. The data on aberration type's frequency showed a predominance of aberrations of chromosome type in the exposed group, mainly including paired acentric fragments, dicentric chromosomes and centric rings. The study showed the dependence of the chromosomal aberration frequency on length of service in uranium mines.

The uranium workers were classified into 3 groups according to the duration of exposure: group I - 1-10 years, II $-11-20$ years and III $-21-25$ years. The received data show that all three groups of workers had higher frequencies of chromosomal aberrations than the control group. In the first group of workers the frequency of dicentrics was higher $(1.95 \pm 0.15)$ than that for the matched control group $(0.50 \pm 0.09)(0.05<p<0.01)$. In the second group of uranium workers the frequency of dicentrics and the total chromosomal aberrations were significantly higher $(2.33 \pm 0.17)$ than in control group $(0.55 \pm 0.08)$. In the third group of workers the frequency of chromosomal aberrations was also significantly higher $(2.68 \pm 0.26)$ than in control group $(0.36 \pm 0.10)$. The frequency of chromosomal aberrations observed in this exposed group III was also higher compared with the first and the second exposed groups $(0.05<p<0.01)$ [72].

Furthermore it was observed a significant increase in the frequency of chromosomal aberrations in the workers who were also heavy smokers compared with those who were moderate smokers or non-smokers. Uranium exposed workers who had inherited the null GSTM1 and/or GSTT1 genotypes had a significant increase in the frequency of chromosome aberrations compared with those who had intact GSTM1 and GSTT1 genes for different group of workers. We have shown that the uranium mining conditions in North Kazakhstan can cause a long-term health risk among the workers.

In uranium miners were observed the various forms of malignant tumors of the lung, liver and stomach [73].

Among human cancers in Kazakhstan, the lung cancer is in the first place (Fig. 3), which represents $11.4 \%$ of the number of cancer patients, while in the structure of morbidity among men leading positions are occupied by the tumor of the trachea, bronchus, and lung (20.4\%) (unpublished observations). During the period from 2002 to 2011 were registered 37,241 lung cancer patients in the Republic of Kazakhstan. Among lung cancer patients was 30554 male $(82.0 \%)$ and 6687 female $(18.0 \%)$ and the ratio was 4.6: 1.0 [74]. In North Kazakhstan there is a highest frequency of cancer in comparison with the other regions of the country [75].

Over the past 30 years in East Kazakhstan there was a sharp increase in cancer rates. This growth is particularly noticeable for the Ust-Kamenogorsk city. The increase in total cancer morbidity indicator is mainly due to an increase in the incidence of lung cancer, breast cancer and skin cancer [76].

As mentioned above, the villages where there is a high radon activity, marked by the territory of Kazakhstan, but are characterized by the highest levels of radon East and North Kazakhstan (67\% of settlements in excess). Interestingly, it is in the Eastern and Northern part of the country there is increased (up to 1.5 times or more) the cancer rates, which makes it possible to assume a correlation between radon levels and cancer incidence [76].

Unfortunately, it has been not enough research of the influence of radon on the risk of cancer for the population in Kazakhstan. In the study of Priest et al., no association between radon and childhood leukemia 


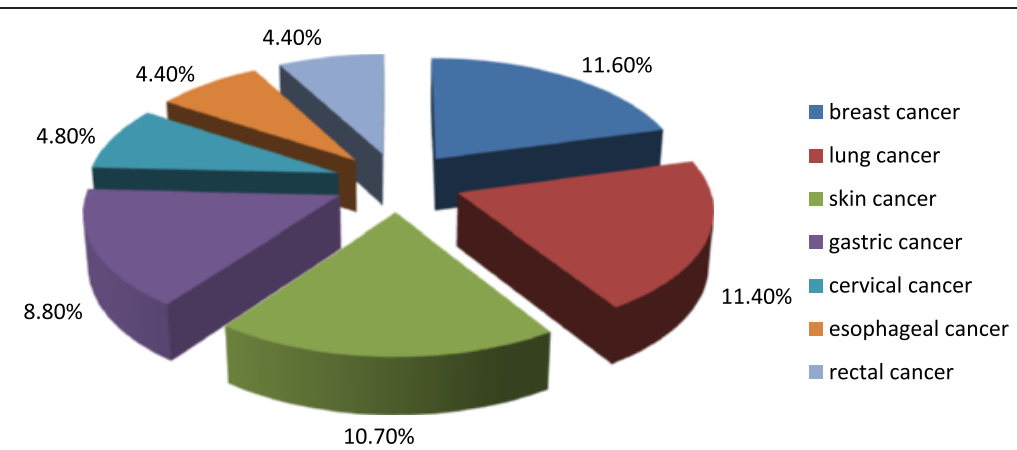

Fig. 3 Structure of cancer in Kazakhstan. (Data of Kazakh Research Institute of Oncology and Radiology, 2011) http://svant.yvision.kz/post/361082? utm_source=digest20130907\&utm_medium=email\&utm_campaign=digest

was found in south Kazakhstan and northern Kyrgyzstan, but the radon concentration was too low (in Kazakhstan was $123 \mathrm{~Bq} / \mathrm{m}^{3}$ and in Kyrgyzstan was $177 \mathrm{~Bq} / \mathrm{m}^{3}$ ) [77].

The strange sleeping sickness in the Kalachi village (North Kazakhstan) was first registered in March 2013 [78]. For two years, people have been experiencing these sudden urges to fall asleep and some people remained sleeping for as long as two days. In January 2015 above one hundred people, including children of Kalachi village, diagnosed with "encephalopathy of unknown etiology" were taken to hospital. Kalachi is located in the vicinity of Krasnogorsk city, where uranium ore mined during the Soviet period. One of the most popular versions of this strange sleeping symptom is the uranium poisoning and the influence of radiation. The experts produced 200 measurements of gamma background outdoor and 100 indoor. The value of gamma background was $0,08-0,14 \mu \mathrm{Sv} / \mathrm{h}$ (at a rate of $0.3 \mu \mathrm{Sv} / \mathrm{h}$ ). Measurements carried out in homes which showed radon levels from 226 to $567 \mathrm{~Bq} / \mathrm{m}$ at a rate of $200 \mathrm{~Bq} / \mathrm{m}^{3}$. However, the cause of the disease has not been established until now [78].

Influence of environmental factors including radon on cancer development among population of North and East Kazakhstan regions were investigated by group of researchers from North Kazakhstan State University. They have found a positive association between residential radon concentration in these two regions of Kazakhstan and different cancer diseases, predominating lung cancer [76].

The problem of radon areas in Kazakhstan is currently defined as one of the most important environmental health problems of the population.

\section{Summary and conclusion}

Many published data have demonstrated the potential of radon exposure to induce biological damage. All these studies suggest that exposure to radon and its progeny can represent a significant public health risk. Radon exposure is considered as the second cause of lung cancer and it is a first in never smokers. Many countries have depicted residential radon exposure maps in order to characterize those areas with the highest indoor radon concentrations.

There are areas in Kazakhstan with a number of factors leading to natural and man-made elevated radioactivity, including numerous sites abnormally elevated natural radioactivity, uranium deposits, as well as longterm activity of uranium mines and mining enterprises other minerals associated with uranium mineralization. Therefore, it becomes clear that exposed human populations should be monitored for risk assessment and disease prevention. Since this topic is very relevant for the Republic of Kazakhstan, it is necessary to conduct the full-scale studies on the risk of radon-induced lung cancer in population living in areas with high levels of radon. These studies conducted in compliance with all requirements of genotoxic studies will provide the extensive and reliable data for a detailed radon zoning of Kazakhstan. It will also provide an opportunity to plan the construction of residential and industrial buildings with the low radon risk exposure. This in turn will help to develop measures to reduce the risk of radon exposures on the health of people living in areas with elevated radon concentrations in the air.

\section{Competing interests}

The authors declare that they have no competing interests.

\section{Authors' contributions}

Both authors made an equal contribution in preparation of manuscript. The authors approved the final manuscript.

\section{Acknowledgements}

The authors gratefully acknowledge A. Keniev for providing the final reports "Studies on the negative impact of natural radioactivity (radon) on public health" (2007) and "The study of the relationship between the concentration of soil radon and its content in the indoor air, the development of the criteria for assessing the areas according to the degree of radon hazard" (2011).

Received: 29 April 2015 Accepted: 10 July 2015

Published online: 01 October 2015 


\section{References}

1. Mikhailov VN. Nuclear Weapons Test and peaceful Nuclear Explosions in the USSR 1949-1990. Moscow: Ministry of the Russian Federation for Atomic Energy and Ministry of Defense of the Russian Federation. Russian Federal Nuclear Center (VNIIEF); 1996.

2. Matsuschenko AM, Tsyrkov GA, Chernyshov AK, Dubasov UV, Krasilov GA Logachev VA, et al. Chronological list of nuclear tests at the Semipalatinsk Test Site and their radiation effects. In: Nuclear Tests. Long-term consequences in the Semipalatinsk/Altai region (Shapiro C.S., Kiselev V.I. and Zaitsev E.V.,Eds.), Springer, Berlin; 1998. pp. 89-97.

3. Simon SL, Baverstock KF, Lindholm C. A summary of evidence on radiation exposures received near to the Semipalatinsk nuclear weapons test site in Kazakhstan. //Health. Phys. 2003;84:718-25.

4. Groshe B, Land C, Bauer S, Pivina LM, Abylkassimova ZN, Gusev BI. Fallout from nuclear tests: health effects in Kazakhstan. Radiat Environ Biophys. 2002:41:75-80.

5. Bersimbaev Rl, Lindholm C, Tankimanova MK, Djansugurova LB, Mamyrbaeva ZZh, Mustonen $\mathrm{R}$, et al. Three generation study of population living the vicinity of the Semipalatinsk nuclear test site biosample database and population characteristics. Helsinki: STUK-Radiation and Nuclear Safety Authority; 2002. (Available at: www.stuk.fi/julkaisut/stuk-a/stuk-a191.pdf).

6. Berikbolov BP, Petrov NN, Karelin VG. Uranium mine ore resources of Kazakhstan. Almaty: Nauka Press; 1996.

7. Stegnar P, Shishkov I, Burkitbayev M, Tolongutov B, Yunusov M, Radyuk R, et al. Assessment of the radiological impact of gamma and radon dose rates at former U mining sites in Central Asia. J Environ Radioact. 2013;123:3-13.

8. Salbu B. Preface: uranium mining legacy issue in Central Asia. J Environ Radioact. 2013;123:1-2.

9. World Nuclear Association. http://www.world-nuclear.org (2015). Accessed 2 Apr 2015.

10. Kazymbet PK. Radioecological state of the residential areas in the uranium mining regions of Kazakhstan. Scientific Proceedings of Institute for Radiobiology and Radiation Protection. 2014;1:19-55 (in Russian).

11. Environment and Sustainable Development in Kazakhstan. A series of UNDP publication in Kazakhstan. №UNDPKAZO6. Almaty; 2004

12. Collier CG, Strong JC, Humphreys JA, Timpson N, Baker ST, Eldred T, et al. Carcinogenicity of radon/radon decay product inhalation in rats - effect of dose, dose rate and unattached fraction. Int J Rad Biol. 2005;81:631-47.

13. Laughlin J. An historical overview of radon and its progeny: applications and health effects. Radiat Prot Dosimetry. 2012;152:2-8.

14. WHO Handbook on Indoor Radon: A Public Health Perspective. Zeeb H, Shannon F, editors. Geneva, Switzerland: World Health Organization; 2009.

15. Sevostyanov VN. The radon problem in Kazakhstan. Almaty: Kazgosinti; 2004. p. 212 (in Russian)

16. Kazatomprom. National Atomic Company: www.kazatomprom.kz (2015). Accessed 06 Apr 2015

17. Zoriy P, Ostapczuk P, Dederichs H, Höbig J, Lennartz R, Zoriy M. Biomonitoring of environmental pollution by thorium and uranium in selected regions of the Republic of Kazakhstan. J Environ Radioact. 2010;101:414-20.

18. The Decree of the Government of the Republic of Kazakhstan on the approval of the program №1006. Supplemental legal system. Almaty; 2002. (in Russian).

19. Husainov AT, Skipin LN, Sofronova LI. Influence of waste uranium companies on ecosystems of North Kazahstan. Kokshetau; 2012 (in Russian).

20. The Tutorial on radioactive waste management for conditions of Kazakhstan. Almaty: Volkovgeologiya; 2002 (in Russian).

21. Kreuzer M, Dufey F, Laurier D, Nowak D, Marsh JW, Schnelzer M, et al. Mortality from internal and external radiation exposure in a cohort of male German uranium millers, 1946-2008. Int Arch Occup Environ Health. 2015;88:431-41.

22. Wilson J, Zuniga MC, Yazzie F, Stearns DM. Synergistic cytotoxicity and DNA strand breaks in cells and plasmid DNA exposed to uranyl acetate and ultraviolet radiation. J Appl Toxicol. 2015;35:338-49.

23. Dublineau I, Souidi M, Gueguen Y, Lestaevel P, Bertho JM, Manens L, et al. Unexpected Lack of Deleterious Effects of Uranium on Physiological Systems following a Chronic Oral Intake in Adult Rat. BioMed Res Int. 2014;2014:181989.

24. Lourenc J, Pereirac R, Pinto F, Caetanoa T, Silva A, Carvalheiroe T, et al. Biomonitoring a human population inhabiting nearby a deactivated uranium mine. Toxicology. 2013;305:89-98.
25. Robertson A, Allen J, Laney R, Curnow A. The Cellular and Molecular Carcinogenic Effects of Radon. Exposure: A Review. Int. J Mol Sci. 2013;14:14024-63.

26. Vogiannis EG, Nikolopoulos D. Radon sources and associated risk in terms of exposure and dose. Environ Health. 2015;2:1-10.

27. ICRP. Radiological Protection against Radon Exposure. ICRP ref 4829-96716554. Draft Report for Consultation. Atlanta, USA: Elsevier; 2011.

28. Popp W, Plappert U, Muller WU, Rehn B, Schneider J, Braun A. Biomarkers of genetic damage and inflammation in blood and bronchoalveolar lavage fluid among former German uranium miners: a pilot study. Radiat Environ Biophys. 2000;39:275-82.

29. Wolff S, Jostes R, Cross FT, Hui TE, Afzal V, Wiencke JK. Adaptive response of human lymphocytes for the repair of radon-induced chromosomal damage.// Mutat. Res. 1991;250:299-306.

30. Smerhovsky Z, Landa K, Rőssner P, Juzova D, Brabec M, Zudova Z, et al. Increased risk of cancer in radon-exposed miners with elevated frequency of chromosomal aberrations. Mutat Res. 2002:514:165-76.

31. Hazar N, Karbakhsh M, Yunesian M, Nedjat S, Naddafi K. Perceived risk of exposure to indoor residential radon and its relationship to willingness to test among health care providers in Tehran. J Environ Health Sci Eng. 2014;12:118.

32. Chen J, Moir D. A Look at the Grouping Effect on Population-level Risk Assessment of Radon-Induced Lung Cancer. Glob J Health Sci. 2013;5(6):1-11.

33. Turner MC, Krewski D, Chen Y, Pope CA, Gapstur S, Thun MJ. Radon and Lung Cancer in the American Cancer Society Cohort. Cancer Epidemiol Biomarkers. 2011;20(3):438-48.

34. Leng S, Picchi MA, Liu Y, Thomas CL, Willis DG, Bernauer AM, et al. Genetic variation in SIRT1 affects susceptibility of lung squamous cell carcinomas in former uranium miners from the Colorado plateau. Carcinogenesis. 2013;34:1044-50

35. Sogl M, Taeger D, Pallapies D, Brüning T, Dufey F, Schnelzer M, et al. Quantitative relationship between silica exposure and lung cancer mortality in German uranium miners, 1946-2003. Br J Cancer. 2012;107:1188-94.

36. Barros-Dios JM, Ruano-Ravina A, Pérez-Ríos M, Castro-Bernárdez M, Abal-Arca J, Tojo-Castro M. Residential Radon Exposure, Histologic Types, and Lung Cancer Risk. A Case-Control Study in Galicia, Spain. Cancer Epidemiol Biomarkers Prev. 2012;21(6):951-8.

37. Taeger $D$, Fritsch $A$, Wiethege $T$, Johnen $G$, Eisenmenger $A$, Wesch $H$, et al. Role of Exposure to Radon and Silicosis on the Cell Type of Lung Carcinoma in German Uranium Miners. Cancer. 2006;106(4):881-9.

38. Alavanja MC, Brownson RC, Lubin JH, Berger E, Chang J, Boice Jr JD. Residential radon exposure and lung cancer among nonsmoking women. J Natl Cancer Inst. 1994;86(24):1829-37.

39. Kreuzer M, Walsh L, Schnelzer M, Tschense A, Grosche B. Radon and risk of extrapulmonary cancers: results of the German uranium miners' cohort study, 1960-2003. Br J Cancer. 2008;99:1946-53.

40. Ruano-Ravina A, Aragonés N, Pérez-Ríos M, López-Abente G, Barros-Dios JM. Residential radon exposure and esophageal cancer. An ecological study from an area with high indoor radon concentration (Galicia, Spain). Int J Radiat Biol. 2014;90(4):299-305.

41. Baradaran S, Maleknasr N, Setayeshi S, Akbari ME. Prediction of Lung Cells Oncogenic Transformation for Induced Radon Progeny Alpha Particles Using Sugarscape Cellular Automata. Iran J Cancer Prev. 2014;1:40-7.

42. Torres-Durán M, Ruano-Ravina A, Parente-Lamelas I, Leiro-Fernández V, Abal-Arca J, Montero-Martínez C, et al. Lung cancer in never-smokers: a case-control study in a radon-prone area (Galicia, Spain). Eur Respir J. 2014;44(4):850-2.

43. Kreuzer M, Gerken M, Kreienbrock L, Wellmann J, Wichmann HE. Lung cancer in lifetime nonsmoking men - results of a case-control study in Germany. Br J Cancer. 2001;84(1):134-40.

44. Méndez D, Alshanqeety O, Warner KE, Lantz PM, Courant PN. The Impact of Declining Smoking on Radon-Related Lung Cancer in the United States. Am J Public Health. 2011;101(2):310-14.

45. Chahine T, Schultz BD, Zartarian VG, Xue J, Subramanian SV, Levy J. Modeling Joint Exposures and Health Outcomes for Cumulative Risk Assessment: The Case of Radon and Smoking. Int J Environ Res Public Health. 2011;8:3688-711.

46. USEPA. EPA Assessment of Risk from Radon in Homes, EPA 402-R-03-003; Office of Air and Radiation. Washington, DC, USA: USEPA; 2003.

47. Darby S, Hill D, Deo H, Auvinen A, Barros-Dios JM, Baysson H, et al. Residential radon and lung cancer-detailed results of a collaborative 
analysis of individual data on 7148 persons with lung cancer and 14208 persons without lung cancer from 13 epidemiologic studies in Europe. Scand J Work Environ Health. 2006;32(Suppl 1):1-84.

48. Neri A, Stewart SL, Angell W. Radon Control Activities for Lung Cancer Prevention in National Comprehensive Cancer Control Program Plans, 2005-2011. Prev Chronic Dis. 2013;10:1-9.

49. Milner J, Shrubsole C, Das P, Jones B, Ridley I, Chalabi Z, et al. Home energy efficiency and radon related risk of lung cancer: modelling study. BMJ. 2014;348:1-12

50. Krewski D, Lubin JH, Zielinski JM, Alavanja M, Catalan VS, Field RW, et al. A combined analysis of North American case-control studies of residential radon and lung cancer. J Toxicol Environ Health. 2006;69:533-97.

51. Peterson E, Aker A, Kim JH, Li Y, Brand K, Copes R. Lung cancer risk from radon in Ontario, Canada: how many lung cancers can we prevent? Cancer Causes Control. 2013;24:2013-20.

52. Canada Health. Cross-Canada survey of radon concentrations in homes final report. Ottawa: Queen's Printer; 2012.

53. Rahmanin YA, Novikov SM, Shashin TA, Abalkina IL. Assessment and reduction of strategic risks in the social sphere. Civil Protection Strategy: Issues and research. 2013;3(2):150-62 (in Russian)

54. Hinojosa de la Garza OR, Sanín LH, Montero Cabrera ME, Serrano Ramirez KI, Martínez Meyer E, Reyes Cortés M. Lung Cancer Mortality and Radon Concentration in a Chronically Exposed Neighborhood in Chihuahua, Mexico: A Geospatial Analysis. ScientificWorldJournal. 2014;2014:935380.

55. Bräuner EV, Andersen CE, Sorensen M, Andersen ZJ, Gravesen P, Ulbak K, et al. Residential radon and lung cancer incidence in a Danish cohort. Environ Res. 2012;118:130-6.

56. Fedorov M (PI), Kayukov P, Bensman V. The study of the relationship between the concentration of soil radon and its content in the indoor air, the development of the criteria for assessing the areas according to the degree of radon hazard. Ministry of Environmental Protection of the Republic of Kazakhstan. Limited Liability Partnership "Ecoservice-C". Final report. Astana; 2011 (in Russian).

57. Fedorov M (PI), Abelenzev V, Bensman V. Studies on the negative impact of natural radioactivity (radon) on public health (final). Ministry of Environmental Protection of the Republic of Kazakhstan. Limited Liability Partnership "Ecoservice-C". Final report. Almaty; 2007 (in Russian).

58. Akhmetov M, Bensman V, Berkinbayev G, Fedorov M. The radon Program of Kazakhstan. RER9.094-9051-01-Regional Workshop on Reducing Risk from Indoor Radon, Geneva, Switzerland; 2010.

59. Fedorov $\mathrm{M}$. Conducting radiation monitoring in the rural settlements. Report 2008-2011 in 4 books. Almaty; 2011 (in Russian).

60. Kazymbet PK, Seisebaev AT. Problems of the complex assessment of radiobioecological situation and health in uranium extraction region of Kazakhstan. Radiobiology, radioecology. 2002;42(6):750-3.

61. Yazikov VG. Uranium Resources of the Republic of Kazakhstan. Uranium and nuclear power. London: The study of uranium Institute; 1993. p. 1137. in Russian.

62. Efremov GF. Hydrogeological survey of aquifers to assess radionuclide contamination. Almaty: Volkovgeologiya; 2001 (in Russian).

63. The sanitary requirements for radiation safety from February 3, № 201. The hygienic regulations. Government of the Republic of Kazakhstan; 2012 (in Russian).

64. The Ministry of healthcare and social development of the Republic of Kazakhstan: https://www.mzsr.gov.kz (2014). Accessed 20 Jan 2015.

65. Klodzinskiy A, Bekenova F, Baydurin S. Features of respiratory function in uranium operators workers suffering from chronic obstructive pulmonary disease. Astana Med J. 2005:3:111-13.

66. Djumasheva R, Kazymbet P. Effect of prolonged exposure of uranium industrial dust to the lungs of humans and animals. Scientific Proceedings of Institute for Radiobiology and Radiation Protection. 2014;1:146-99 (in Russian).

67. Bekenova F, Baydurin S, Klodzinskiy A, Zhautikova B. The prevalence of diseases of the internal organs in the cohort of the workers Stepnogorsk Mining Factory. Clinical Medicine of Kazakhstan. 2006;2:16-8 (in Russian).

68. Ahmedyanova $\mathrm{H}$, Ivashevskaya $\mathrm{R}$, Ibrayeva Z. Influence of anthropogenic factors on the course of pregnancy and childbirth in women living in the uranium mining regions. Astana Med J. 2005;3:89-90 (in Russian).

69. Raisova KA. Analysis of the children incidence in uranium mining regions of Akmola. Astana Med J. 2005:3:129-31 (in Russian).
70. Kakabaev AA, Sharipov IK, Bersimbaev Rl. A cytogenetic study of Kazakhstan uranium mine workers. Russian J Cytol. 1998;41(3,4):274

71. Kakabaev AA, Sharipov IK, Bersimbaev RI. Chromosome aberrations in the group of uranium mine workers in North Kazakhstan. Proc Kazakhstan Acad Sci (SerBiology). 1999;1:10-5.

72. Toksobayeva GA, Kakabayev AA, Bersimbaev RI. Investigation of chromosomal aberration frequencies and glutathione-s-transferase M1 and $\mathrm{T} 1$ genes in workers occupationally exposed to uranium in northern Kazakhstan. NATO Security through science series E, Human and Societal Dynamics. 2010;73:177-82.

73. Kreuzer M, Grosche B, Schnelzer M, Tschense A, Dufey F, Walsh L. Radon and risk of death from cancer and cardiovascular diseases in the German uranium miners cohort study: follow-up 1946-2003. Radiat Environ Biophys. 2010;49(2):177-85

74. Nurgaziyev SHK, Seytkazina GD. The frequency of lung cancer in Kazakhstan for 10 years. Siberian J Oncol. 2013;2:54-5 (in Russian).

75. Monitoring the effectiveness of charges of the state budget for prevention and treatment of cancer . Soros Foundation-Kazakhstan; 2013 (in Russian).

76. Beletskaya $\mathrm{N}$. Effect of environmental factors on cancer incidence in the population of North Kazakhstan and East Kazakhstan. Petropavlovsk: Kozybayev M.SKGU; 2013. p. 225 (in Russian).

77. Priest ND, Hoel D, Uralbekov B, Baizakova DO, Burkitbayev M. Childhood exposures to $\mathrm{Rn}-222$ and background gamma radiation in the uranium provinces of south Kazakhstan and northern Kyrgyzstan.//. J Environ Radioact. 2013;123:99-103.

78. BNews.kz: http://bnews.kz/ (2014). Accessed 27 Nov 2014

\section{Submit your next manuscript to BioMed Central and take full advantage of:}

- Convenient online submission

- Thorough peer review

- No space constraints or color figure charges

- Immediate publication on acceptance

- Inclusion in PubMed, CAS, Scopus and Google Scholar

- Research which is freely available for redistribution 